\title{
Effect of enzyme supplementation on the performance of broilers fed maize, wheat, barley or micronized dehulled barley diets
}

\author{
Y.-L. Yin ${ }^{1,2}$, S.K. Baidoo ${ }^{1,3}$ and J.L.L. Boychuk ${ }^{1}$ \\ 'Department of Animal Science, University of Maniloba \\ Winnipeg, MB R3T 2N2, Canada \\ 'Changsha Institute of Agricultural Modernization, The Chinese Academy of Science \\ P.R. China \\ 'Southern Experiment Station, University of Minnesota \\ Waseca, MN 56093, USA
}

(Received 18 January 2000; accepted 15 July 2000)

\begin{abstract}
The effects of an enzyme preparation on the performance and carcass characteristics of broilers fed diets based on maize, wheat, huiled barley (Bedford) or micronized dehulled barley (MDB) (Bedford) diets were evaluated. A commercial enzyme containing $\beta$-glucanase and xylanase was used. One thousand and nine hundred-twenty one-day-old broiler were used for this study. The broilers fed the MDB diets had a lower average daily gain $(\Lambda D G)(P<0.05)$ and lower average daily fecd intake $(\mathrm{ADFI})(\mathrm{P}<0.05)$ than the broilers fed the other diets. There was a significant period $\mathrm{x}$ grain interaction $(\mathrm{P}<0.05)$ for $\mathrm{ADG}$ with the broilers on the barley diets performing better in the grower phase. The broilers received enzymes showed an enzyme $x$ period interaction with the feed conversion rate (FCR) of those birds in the starter phase doing better $(\mathrm{P}<0.05)$ than in the grower phase compared to those fed the unsupplemented diets. The birds fed MDB diets had higher digesta viscosity than birds fed unprocessed barley, maize or wheat diets $(\mathrm{P}<0.01)$. Feed enzyme addition to the MDB diet caused a decrease $(\mathrm{P}<0.01)$ in the digesta viscosity by $49 \%$ and an improvement $(\mathrm{P}<0.05)$ feed conversion ratio (FCR) both for the starter and the grower phase.
\end{abstract}

KEY WORDS: micronized barley, maize, wheat, feed enzyme, broilers

\footnotetext{
Corresponding author
} 


\section{INTRODUCTION}

Cereal grains are major source of energy in livestock diets. The amount of energy available to the animal from the cereal is influenced by the amount and the amount and type of cell wall polysaccharides. Mixed-linked $\beta$-glucans are the predominant non-starch polysaccharides (NSP) in barley, while arabinoxylans are the main NSP in wheat (Schulze et al., 1996). This NSP creates a viscous environment in the intestinal tract of broilers, and results in reduced nutrient utilisation. Birds fed hull-less barley appears to have a higher viscosity than hulled barley (Classen et al., 1985). Poorer nutritive value of hull-less barley may be related to its high content of water-soluble $\beta$-glucans (Newman and Newman, 1987) and high viscosity compared with hulled barley (Rotter et al., 1989). Although much rescarch has indicated that the anti-nutritive propertics of barley and wheat can be overcome by the addition of NSP-degrading enzymes in the diet (Hessclman and Aman, 1986; Bedford and Classen, 1992), no research for broiler growth performance by enzyme addition to micronized barley have been reported in the literature (Preston, 1997). The objective of this study were to compare the reaction of birds fed diets based on unprocessed hulled barley or micronized dehulled barley, supplemented vs unsupplemented with enzymes. Diets based on wheat and maize were used as control.

\section{MATERIAL AND METHODS}

\section{Experimental diets}

Dietary treatments differed by the grain type used, and each grain was fed with or without enzyme supplementation (Tables 1 and 2). The grains used were maize, wheat, hulled barley (Bedford) and micronized dehulled barley (MDB). To prepare the MDB, the same batch of barley was dehulled and moistened to $22 \%$ and then micronized on the table of the WestCan Micronizer vibrating at a frequency of 1200 million megacycles for $45 \mathrm{sec}$ at a temperature of $103^{\circ} \mathrm{C}$. A commercial enzyme Avizyme 1100 , in a dose $1 \mathrm{~g} / \mathrm{kg}$ of diet, that contains $\beta$-glucanase, xylanase and protease activities, provided by Finnfeeds International Ltd. was used.

The feed was fed in a crumbled form and available ad libitum from selffeeders. All diets werc formulated to be close to isoenergenic, lysine, methionine and threonine. Diets containing about $230 \mathrm{~g} \mathrm{~kg}^{-1}$ crude protein (CP) and $2942 \mathrm{kcal} \mathrm{kg}^{-1}$ metabolisable encrgy (ME) were fed for 20 days and diets containing about $200 \mathrm{~g} \mathrm{~kg}^{-1} \mathrm{CP}$ and $2830 \mathrm{kcal} \mathrm{kg}^{-1} \mathrm{ME}$ were fed for the last 20 days.

Water was available free choice for all birds. All diets met or exceeded the nutrient requirements of the National Research Council (1988) for poultry. 
TABLE 1

Formula and analysis for the staner diets of broilers fed maize, wheat, hulled barley or micronized dehulled barley (MDB), $\mathrm{g} \mathrm{kg}^{-1}$ on fed basis ${ }^{\natural}$

\begin{tabular}{|c|c|c|c|c|}
\hline & Maizc & Wheat & Hulled barley & MDB \\
\hline Wheat & - & 592.1 & - & - \\
\hline Maize & 532.3 & - & - & - \\
\hline $\mathrm{MDB}^{3}$ & - & - & - & 541.3 \\
\hline Barley & - & - & 506.9 & - \\
\hline Soyabean meal & 350.0 & 277.0 & 320.0 & 315.0 \\
\hline Meat meal & 56.8 & 56.8 & 56.7 & 56.7 \\
\hline Canola oil & 29.0 & 43.0 & 85.0 & 54.0 \\
\hline Constant $^{2}$ & 29.4 & 29.4 & 29.4 & 29.4 \\
\hline Lysine & - & 0.13 & - & 1.10 \\
\hline Methionine & 2.23 & 1.27 & 2.00 & 2.00 \\
\hline Threonine & - & 0.3 & - & 0.5 \\
\hline \multicolumn{5}{|l|}{ Chemical analysis } \\
\hline crude protein & 236.3 & 227.9 & 220.4 & 226.9 \\
\hline lysine & 13.0 & 13.1 & 13.0 & 13.2 \\
\hline methionine & 5.7 & 5.6 & 5.6 & 5.7 \\
\hline threonine & 8.7 & 8.6 & 8.5 & 8.5 \\
\hline dry matter & 905.0 & 913.0 & 914.0 & 923.5 \\
\hline Energy, $\mathrm{ME} \mathrm{kcal} \mathrm{kg^{-1 }}$ & 2942.4 & 2941.8 & 2942.7 & 2942.5 \\
\hline
\end{tabular}

1 in supplemental diets $1 \mathrm{~g} / \mathrm{kg}$ of enzyme substiluted equal amount of cereal grain

2 constant components per $\mathrm{kg}$ of diet: limestone 7.8 ; dicalcium phosphatc 9.7 ; iodized salt 1.9 ; manganese $50 \mathrm{mg}$; zinc $27 \mathrm{mg}$; iron $80 \mathrm{mg}$; copper $80 \mathrm{mg}$; iodine $1 \mathrm{mg}$; selenium $0.1 \mathrm{mg}$ : vitamin A $12400 \mathrm{I} \mu$; vitamin $\mathrm{D}_{1} 2700 \mathrm{I} \mu$; vitamin E $20 \mathrm{mg}$; thiamin $3.25 \mathrm{mg}$; riboflavin $4.5 \mathrm{mg}$; niacin $14 \mathrm{mg}$; calcium pantothenate $9 \mathrm{mg}$; chorine $315 \mathrm{mg}$; pyridoxine $2 \mathrm{mg}$; folicacid $1.2 \mathrm{mg}$; biotin $150 \mathrm{mg}$ : vitamin $\mathrm{B}_{12} 15 \mathrm{mg}$

$\because$ micronized dehulled barley

\section{Experimental animals}

One thousand nine hundred-twenty one-day-old commercial broiler chickens were randomly divided to pens with 60 birds in each pen, 8 dietary treatments with 4 pens per treatment (Table 1).

\section{Data collection}

Body weight and feed consumption were recorded at 20 and 40 days of age corrected for mortality and used to calculate average daily gain (ADG), average daily feed intake (ADFI) and feed conversion rate (FCR). Viscosity measurements were taken at day 20 of age on five randomly selected birds per pen. The birds 
TABLE 2

Formula and analysis for the grower diets of broilers fed ma, wheat, hulled barley or micronized dehulled barley (MDB), $\mathrm{g} \mathrm{kg}^{-1}$ on fed basis'

\begin{tabular}{|c|c|c|c|c|}
\hline Indices & Maize & Wheat & Hulled barley & $\mathrm{MDB}^{3}$ \\
\hline Wheat & - & 699.3 & - & - \\
\hline Maize & 628.9 & - & - & - \\
\hline $\mathrm{MDB}^{3}$ & - & - & - & 612.6 \\
\hline Barley & - & - & 607.5 & - \\
\hline Meat meal & 56.7 & 56.7 & 56.7 & 56.7 \\
\hline Soyabean meal & 267.5 & 180.0 & 227.3 & 232.5 \\
\hline Constant ${ }^{2}$ & 29.4 & 29.4 & 29.4 & 29.4 \\
\hline Canola oil & 17.0 & 33.5 & 77.5 & 67.5 \\
\hline Lysine & - & 0.3 & - & 0.5 \\
\hline Methionine & - & - & 0.8 & 0.3 \\
\hline Threonine & - & 0.9 & 0.3 & 0.5 \\
\hline \multicolumn{5}{|l|}{ Chemical analysis } \\
\hline crude protein & 221.8 & 218.4 & 192.1 & 185.5 \\
\hline lysine & 12.0 & 11.9 & 11.9 & 11.9 \\
\hline methionine & 3.2 & 3.3 & 3.3 & 3.3 \\
\hline thrconine & 7.6 & 7.5 & 7.5 & 7.6 \\
\hline dry matter & 903.0 & 903.0 & 919.0 & 931.5 \\
\hline Energy, ME kcal kg' ${ }^{\prime}$ & 2827 & 2830 & 2829 & 2830 \\
\hline
\end{tabular}

1 in supplemental diets $1 \mathrm{~g} / \mathrm{kg}$ of enzyme substituted cqual amount of cereal grain

2 constant components per $\mathrm{kg}$ of diet: limestone 7.8; dicalcium phosphate 9.7; iodized salt 1.9; manganese $50 \mathrm{mg}$; zinc $27 \mathrm{mg}$; iron $80 \mathrm{mg}$; copper $80 \mathrm{mg}$; iodine $1 \mathrm{mg}$; selenium $0.1 \mathrm{mg}$; vitamin A $12400 \mathrm{I} \mu$ : vitamin $\mathrm{D}_{3} 2700 \mathrm{~J} \mu$; vitamin E $20 \mathrm{mg}$; thiamin $3.25 \mathrm{mg}$; riboflavin $4.5 \mathrm{mg}$; niacin $14 \mathrm{mg}$; calcium pantothenate $9 \mathrm{mg}$; chorine $315 \mathrm{mg}$; pyridoxine $2 \mathrm{mg}$; folic acid $1.2 \mathrm{mg}$; biotin $150 \mathrm{mg}$; vitamin $\mathrm{B}_{12} 15 \mathrm{mg}$

as in Table 1

werc killed and the contents of the ileum of cach selected bird was collected and centrifuged. The supernatant was pipeted off, and the viscosity measurement was taken twice for each sample using a Brookfield digital plate viscometer (Model DV-II) (Veldman and Vahl, 1994). Random sclection of birds for carcass evaluation occurred at 40 days of age. Fourteen birds, half of male and half of female per treatment, were killed and carcass weight, dressing percentage (hot and chilled), abdominal fat and breast filct yield were estimated.

\section{Chemical and statistical analysis}

Fecd samples were ground in a Testator cyclone 1093 sample mill (Hoganas, Sweden). Dry matter, crude protein, calcium and phosphorus were determined ac- 
cording to AOAC (1990). Gross energy was determined by using an adiabatic oxygen bomb calorimeter (Parr, model 1241).

Average daily gain, average daily feed intake, and feed efficiency were analyzed by analysis of variance using the General Linear Modeling (GLM) in the Statistical Analysis System (SAS Institute Inc, 1988). This expcriment was a completely randomized design, with a $4 \times 2$ factorial arrangement of treatments, in which animals were randomly assigned to onc of the four grains, and with or without enzyme supplementation. This was further split by period.

Differences between means were compared using the Student-Neuman-Keuls (SNK) method at a significance level of $\mathrm{P}<0.05$ (Snedecor and Cochran, 1967).

\section{RESULTS AND DISCUSSION}

\section{Overall performance}

The overall performance of the broilers is given in Table 3 . The broilers fed the MDB diets had a lower ADG $(\mathrm{P}<0.05)$ and ADFI $(\mathrm{P}<0.05)$ than the broilers fed the maize, wheat or unprocessed barley diets. The possibility that difference between groups might be caused by difference in chemical composition of diets, c.g. the crude protein in the starter and grower diets of the MDB diet were 4 and $20 \%$ lower, respectively, than that in the maize diet, although the levels of lysine, methionine, threonine and ME were almost the same between the groups (Tables 1 and 2). Another possibility that the difference might be due to different nutrition utilisation between the ccreals. For example, the viscosity that occurs due to the gelatinized starch produced by micronization may affect the absorption of nitrogen and carbohydrate (Hesselman and Åman, 1986), which will be discussed later in this paper. There were no differences $(\mathrm{P}>0.05)$ in the overall FCR between the cereal grain diets. Although there was no significant enzyme effects $(\mathrm{P}>0.05)$ in the overall performance of the broilers, there was a significant grain $x$ enzyme interaction $(P<0.05)$ for the FCR with a better performance for the enzyme addition diets. The broilers fed the wheat, maize or hulled barley diets without enzyme had higher ADG of $4.8,4.5$ and 3.6\%, respectively $(\mathrm{P}>0.05)$, compared to those fed the MDB without enzyme diet. The broilers fed MDB without enzyme diet had a $3.5 \%$ decrease in the ADG compared to those fed the hulled barley without enzyme diet. This is similar to the $3.5 \%$ difference of the overall grain effect with the ADG between the broilers fed MDB or hulled barley diets. 
TABLE 3

The overall performance of broilers as affected by the feeding of maize, wheat, hulled barley or micronized dehulled barley (MDB) with ( + ) or without (-) enzyme supplementaion (1-40 days)

\begin{tabular}{|c|c|c|c|c|c|c|c|c|c|c|}
\hline & $\mathrm{BWG}^{\prime} \mathrm{g}$ & $\mathrm{ADG}^{2} \mathrm{~g}$ & $\mathrm{SEM}^{3}$ & $\mathrm{Sig}^{4}$ & $\mathrm{FI}^{5} \mathrm{~g}$ & SEM & Sig & $\mathrm{FCR}^{6}$ & SEM & Sig \\
\hline maize & 2338.6 & $58.4 \mathrm{~b}$ & 0.41 & * & $105.3 a$ & 0.72 & * & 1.80 & 0.02 & NS \\
\hline hulled Barley & 2318.1 & $57.8 \mathrm{~b}$ & & & $103.9 \mathrm{a}$ & & & 1.80 & & \\
\hline MDB & 2231.4 & $55.7 \mathrm{a}$ & & & $100.6^{b}$ & & & 1.81 & & \\
\hline- & 2292.6 & 57.1 & & & 103.3 & & & 1.81 & & \\
\hline \multicolumn{11}{|l|}{ Grain $x$ enzyme } \\
\hline maize+ & 2349.7 & 58.8 & 0.51 & NS & 105.7 & 1.02 & NS & $1.80^{\mathrm{ab}}$ & 0.02 & $*$ \\
\hline maize - & 2327.5 & 58.0 & & & 104.8 & & & $1.81^{\mathrm{a}}$ & & \\
\hline wheat + & 2321.0 & 58.6 & & & 106.1 & & & $1.81^{\mathrm{a}}$ & & \\
\hline MDB - & 2224.0 & 55.3 & & & 101.7 & & & $1.89^{\mathrm{a}}$ & & \\
\hline
\end{tabular}

${ }^{1}$ body weight gain; ${ }^{2}$ average daily gain; ${ }^{3}$ pooled standard error of the means; ${ }^{4}$ statistically significant, $*=$ significant at $\mathrm{P}<0.05$ and $\mathrm{NS}=$ non significant at $\mathrm{P}>0.05 ;{ }^{5}$ average daily feed intake; ${ }^{6}$ feed conversion ratio 


\section{Effect $x$ period interactions}

The results of Table 4 showed that there was a significant period $x$ grain interaction $(\mathrm{P}<0.05)$ for ADG with the broilers on the unprocessed barlcy diets performing relatively better in the grower phase than in the starter phase. There was also an enzyme $x$ period interaction $(\mathrm{P}<0.05)$, with the broilers fed enzymes doing better in the starter phase than in the grower phase compared to those broilers fed the non-supplemented diets. A grain $\mathrm{x}$ enzyme $\mathrm{x}$ period interaction $(\mathrm{P}<0.05)$ occurred with the broilers fed the MDB with enzyme diet having a better FCR in the both starter and grower phases than those fed the MDB without enzyme dict. Similar to the results of MDB diet, the broilers fed the unprocessed barley with enzymc diet in the starter phase had a better $(\mathrm{P}<0.05) \mathrm{FCR}$ than that of the without enzyme addition diet, but there was no grain $\mathrm{x}$ enzyme interaction effect for the grower phase. The low productive value of unsupplemented barley when fed to broiler chickens has been attributed to $\beta$-glucans, which causes highly viscous conditions in the small intestine and interferes with nutrient absorption (Burnett, 1966). The FCR of the broilers fed MDB with enzyme diet was 3.4 and $4.0 \%$ better in the starter phase and grower phase, respectively, compared with the broilers fed the MDB without enzyme diet. However, these responses are much lower than those reported by Brenes et al. (1993), who reported a marked improvement in feed consumption, weight gain, feed conversion and a reduced mortality in birds fed barley-based diets with enzymes. The present study shows enzyme addition did not improve the ADFI and reduce mortality.

\section{Carcass evaluation}

A significant difference $(\mathrm{P}<0.05)$ was seen in the liveweight analysis of the broilers, with the hulled barley dicts and the MDB without enzyme diet having lower liveweights than the wheat based diet (Table 5). The birds fed the MDB with enzyme diet were $3.7 \%$ heavier than those fed the MDB dict without enzyme supplementation. There was also a decrease of $4.4 \%$ in the dressed weight of the birds fcd the MDB without enzyme compared to those fed the MDB enzyme diet. There was a significant decrease in the dressed weight $(\mathrm{P}<0.05)$ of birds fed the hulled barley with enzyme or the MDB without enzyme diets compared with the broilers fed the wheat with enzyme dict. The lower dressed weight is expected for the broilers fed the MDB without enzyme diet since these broilers had poorer ADG throughout the study. The breast weight for the birds fed the MDB with enzyme diet was $6.0 \%$ higher than those fed the MDB without enzyme diet. 
TABLE 4

The performance of broilers fed maize, wheat, hulled barley and micronized dehulled barley (MDB) with and without enzyme supplementation. Values are means \pm SEM for effect $x$ period interaction

\begin{tabular}{|c|c|c|c|c|c|c|c|c|}
\hline & \multicolumn{2}{|c|}{ Body weight, g } & \multicolumn{2}{|c|}{ Average daily gain, $g$} & \multicolumn{2}{|c|}{ Average daily feed intake, $\mathrm{g}$} & \multicolumn{2}{|c|}{ Feed conversion ratio } \\
\hline & 20 day & 40 day & 20 day & 40 day & $0-20$ day & 20-40 day & $0-20$ day & 20-40 day \\
\hline \multicolumn{9}{|l|}{ Grain } \\
\hline maize & 714.8 & 2381.8 & $33.9^{a}$ & $83.0^{\circ}$ & $48.8^{a}$ & $170.2^{\text {th }}$ & $1.44^{\mathrm{b}}$ & $2.05^{h}$ \\
\hline wheat & 712.2 & 2361.3 & $33.8^{a}$ & $82.6^{\mathrm{ath}}$ & $49.0^{\mathrm{a}}$ & $174.3^{3}$ & $1.45^{\text {ab }}$ & $2.11^{\mathrm{a}}$ \\
\hline hulled barley & 651.8 & 2361.3 & $30.6^{b}$ & $84.9^{\circ}$ & $44.7^{b}$ & $170.6^{\text {ah }}$ & $1.46^{\mathrm{ub}}$ & $2.01^{\mathrm{h}}$ \\
\hline MDB & 631.3 & 2274.6 & $29.6^{\mathrm{h}}$ & $81.8^{b}$ & $43.5^{\mathrm{h}}$ & $165.2^{\mathrm{h}}$ & $1.47^{\mathrm{a}}$ & $2.02^{b}$ \\
\hline SEM & & & 0.56 & 0.57 & 0.52 & 0.60 & 0.02 & 0.02 \\
\hline Significance & & & $<0.05$ & $<0.05$ & $<0.05$ & $<0.05$ & $<0.05$ & $<0.05$ \\
\hline \multicolumn{9}{|l|}{ Enzyme } \\
\hline+ & 680.7 & 2353.6 & 32.2 & 84.2 & 46.4 & 170.9 & $1.44^{\mathrm{h}}$ & 2.03 \\
\hline- & 674.4 & 2335.8 & 31.8 & 83.0 & 46.7 & 170.2 & $1.47^{4}$ & 2.05 \\
\hline SEM & & & 0.40 & 0.40 & 0.30 & 0.30 & 0.02 & 0.03 \\
\hline Significance & & & NS & NS & NS & NS & NS & NS \\
\hline \multicolumn{9}{|l|}{ Grain $x$ enzyme } \\
\hline maize+ & 717.3 & 2392.8 & 34.1 & 84.7 & $48.8^{a}$ & $171.9^{a}$ & $1.43^{a}$ & $2.03^{4}$ \\
\hline maize- & 712.3 & 2370.7 & 33.7 & 84.1 & $48.9^{4}$ & $169.9^{4}$ & $1.45^{\mathrm{h}}$ & $2.02^{4}$ \\
\hline wheat+ & 709.0 & 2364.2 & 33.7 & 83.5 & $48.9^{a}$ & $172.8^{\mathrm{a}}$ & $1.45^{\mathrm{h}}$ & $2.07^{4}$ \\
\hline wheat- & 715.3 & 2358.3 & 33.9 & 81.3 & $49.5^{\circ}$ & $168.3^{b}$ & $1.46^{\mathrm{b}}$ & $2.07^{4}$ \\
\hline barley+ & 671.4 & 2375.5 & 31.6 & 84.9 & $44.9^{\mathrm{h}}$ & $174.0^{4}$ & $1.42^{\mathrm{h}}$ & $2.05^{\prime \prime}$ \\
\hline barley- & 632.3 & 2347.0 & 29.7 & 85.3 & $44.3^{\mathrm{bc}}$ & $175.7^{\mathrm{a}}$ & $1.49^{a}$ & $2.06^{4}$ \\
\hline $\mathrm{MDB}^{2}+$ & 625.1 & 2282.0 & 29.3 & 83.7 & $42.5^{\circ}$ & $165.7^{\mathrm{h}}$ & $1.45^{\mathrm{h}}$ & $1.98^{\mathrm{h}}$ \\
\hline $\mathrm{MDB}^{2}-$ & 637.5 & 2267.2 & 29.8 & 81.3 & $44.7^{h}$ & $167.5^{\mathrm{h}}$ & $1.50^{a}$ & $2.06^{4}$ \\
\hline SEM $^{1}$ & & & 0.81 & 0.81 & 0.82 & 0.84 & 0.03 & 0.03 \\
\hline Significance & & & NS & NS & $<0.05$ & $<0.05$ & $<0.05$ & $<0.05$ \\
\hline
\end{tabular}


TABLE 5

Carcass cvaluation of broilers fed wheat, hulled barley or micronized barley (MDB) with (+) and without (-) enzyme supplementatio

\begin{tabular}{|c|c|c|c|c|c|c|c|c|}
\hline \multirow{2}{*}{$\begin{array}{l}\text { Treatment } \\
\text { Enzyme }\end{array}$} & \multicolumn{2}{|c|}{ Wheat } & \multicolumn{2}{|c|}{ Hulled barley } & \multicolumn{2}{|c|}{$\mathrm{MDB}$} & \multirow[t]{2}{*}{ SEM $^{\prime}$} & \multirow[t]{2}{*}{ Significant $^{2}$} \\
\hline & + & - & + & - & + & - & & \\
\hline Liveweight, g & 2725 & 2657 & 2556 & 2582.4 & 2640 & 2545 & 44.5 & * \\
\hline Breast weight ${ }^{3}, \mathrm{~g}$ & 441.6 & 434.9 & 411 & 424.5 & 426.8 & 402.7 & 10.96 & NS \\
\hline Cold dressing, $\%$ & 67.4 & 72.9 & 71.3 & 72.75 & 67.1 & 71 & 2.77 & NS \\
\hline
\end{tabular}

1 number of birds per treatment $=14$ (half of male and half of female)

$2 *=$ statistical significance at $\mathrm{P}<0.05 ; \mathrm{NS}=$ non significant at $\mathrm{P}>0.05$

" weight of deboned breast filet

TABLE 6

Digesta viscosity (unit, $\mathrm{cp}$ ) measurements of broilers fed maize, wheat, hulled barley and micronized dehulled barley (MDB) with ( + ) and without (-) enzyme supplementation

\begin{tabular}{|c|c|c|c|c|c|c|c|c|c|c|}
\hline \multirow{2}{*}{$\begin{array}{l}\text { Grain } \\
\text { Treatment }\end{array}$} & \multicolumn{2}{|c|}{ Maize } & \multicolumn{2}{|c|}{ Wheat } & \multicolumn{2}{|c|}{ Hulled barley } & \multicolumn{2}{|c|}{$\mathrm{MDB}$} & \multirow[t]{2}{*}{ SEM $^{1}$} & \multirow[t]{2}{*}{$\mathrm{Sig}^{2}$} \\
\hline & + & - & + & . & + & - & + & - & & \\
\hline Viscosity & $2.85^{\mathrm{b}}$ & $2.42^{b}$ & $3.29 \mathrm{~b}$ & $3.98^{b}$ & $5.1^{b}$ & $4.79^{b}$ & $4.91^{\mathrm{b}}$ & $7.32^{\mathrm{a}}$ & 0.635 & $* *$ \\
\hline
\end{tabular}

${ }^{1}$ pooled standard error of the means

$2 * *$ statistical significance at $\mathrm{P}<0.01$ 
Viscosity measurements

The results of the viscosity measurements (Table 6) show there were differences in the viscosity of the digesta of the birds fed the various diets $(\mathrm{P}<0.01)$. The digesta from broilers fed the hulled barley and the MDB diets showed higher viscosity than those fed the maize or wheat diets. Barley $\beta$-glucans increase the digesta viscosity and thereby decrease the absorption of nitrogen and carbohydrate (Hesselman and Åman, 1986). The birds fed the hulled barley without enzyme diet had lower digesta viscosity than those fed the MDB diets. The viscosity of the MDB dict without enzymes is very high, which may be explained by the changes the starches undergo during starch gelatinization. Thacker (1999) reported that micronization increased the percentage of gelatinized starch in both grower and finisher pig diet, based on hulless barley, by 22 and $17 \%$, respectively. This would explain the poorer performance of the birds on the MDB diets. It appears that the mechanical dehulling and further processing by micronization increases the gelatinized starch content, and therefore increased the digesta viscosity. This high viscosity product is poorly absorbed in the gastrointestinal tract, and the poor performance of the birds reflects this inability to utilize the diet. An improved FCR for the MDB based diet with enzyme addition might be duc to the significantly decreased viscosity in the bird small intestine.

In summary it can be concluded that birds fed a micronized dehulled barley had a lower feed intake and high viscosity in the small intestine, compared to maize, wheat and unprocessed barley diets. Feed enzyme addition can reduce small intestine viscosity and improve feed conversion ratio for the dehulled micronized barley.

\section{ACKNOWLEDGMENTS}

We thank Finnfecds International Ltd. and Precision Feeds Ltd. for financial support. 


\section{REFERENCES}

Allen C.M., Bedford M.R., McCracken K.J., 1995. A synergistic response to enzyme and antibiotic supplementation of wheat-based diets for broilers. Proceeding of the $10^{\text {th }}$ European Symposium on Poultry Nutrition. Antalya (Turkey), pp. 369-370

Association of Official Analytical Chemists (AOAC), 1990. Official Methods of Analysis. $15^{\text {th }}$ Edition. Association of Analytical Chemists. Washington, DC

Bedford M.R., Classen H.L., 1992. Reduction of intestinal viscosity through manipulation of dietary rye and pentosanase concentration is aftected through changes in carbohydrate composition of the intestinal aqueous phase and results in improved growth rate and fecd conversion efficiency of broiler chicks. J. Nutr. 122, 560-569

Chesson A., 1993. Feed enzymes. Anim. Feed Sci. Tech. 45, 65-79

Classen H.L., Campbell G.L., Rossnagel B.G., Bhatty R., Reichert R.D., 1985. Studies on the usc of hulless barlcy in chick diets: Deleterious effects and methods of alleviation. Can. J. Anim. Sci. 65, 725-733

Choct M., Hughes R.J., Trimble R.P., Annison G., 1994. The use of enzymes in low-ME wheat broiler diets: effect on bird pertormance and gut viscosity. Proc. Aust. Poultry Sci. Symp. 6, 83-87

Hesselman K., Åman P., 1986. The effect of $\beta$-glucanase on the utilization of starch and nitrogen by broiler chickens fed on barley of high or low viscosity. Anim. Feed Sci. Tech. 15, 83-93

National Research Council (NRC), 1988. Nutrient Requirements of Swine. $9^{\text {th }}$ revised Edition. NASNRC. Washington, DC

Newman R.K., Newman C.W., 1987. $\beta$-glucanase effect on the performance of broiler chickens fed covered and hulless barley isotopes having normal and waxy starch. Nutr. Rep. Int. 36, 693-699

Preston C.M., 1997. Effect of processing and feed enzyme inclusion in wheat-based diet for broilers. PhD Thesis. The Queen's University of Belfast

Rotter B.A., Marquardt R.R., Guenter W., Biliaderis C., Newman C.W., 1989. In vitro viscosity measurement of barley extracts as predictors of growth responses in chicks fed barley-based diets supplemented with fungal enzyme preparations. Can. J. Anim. Sci. 69, 431-439

Shulze H.. Partridge G.G., Gill B.P., 1996. The use of different xylanase sources and a protease in wheat-based diets for weaned pigs. Anim. Sci. 62, 665 (Abstr.)

Snedecor G.W. Cochran , 1967. Statistics Methods. $6^{\text {th }}$ Edition. Iowa State University Press. Ames (USA)

Statistical Analysis System Institute Inc. (SAS), 1988. SAS User's Guide. Statistics 1986 Edition. SAS Institute, Inc. Cary, NC. (USA)

Thacker P.A., 1999. Effect of micronization on the performance of growing/finishing pigs fed diets based on bulled and hulless barley. Anim. Feed Sci. Tech. 79, 29-41

Veldman A., Vahl H.A., 1994. Xylanase in broiler diets with differences in characteristics and content of wheat. Brit. Poultry Sci. $35,537-550$ 


\section{STRESZCZENIE}

\section{Wpływ dodatku enzymu na wyniki produkcyjne broilerów żywionych dietami zawierającymi} kukurydzę, pszenicę, jęczmień lub mikronizowany odluszczony jęczmień

Badano wpływ dodatku handlowego preparatu enzymatycznego zawierającego $\beta$-glulanazę i ksylanazę na wyniki produkcyjne i jakość tuszy broilerów żywionych dietami, opartymi na kukurydzy, pszcnicy, jęczmicniu (Bedford) lub mikronizowanym odłuszczonym jęczmieniu (MBD) (Bedford). Do doświadczenia użyto tysiąc dziewięćset dwadzieścia jednodniowych piskląt. Kurczçta otrzymujące dawkę MBD pobicrały mnicj paszy $(\mathbf{P}<0,05)$ i miały mniejsze dzienne przyrosty $(\mathrm{P}<0,05)$ niż kurczęta $z$ pozostałych grup. Stwicrdzono istotną interakcję okres $\mathrm{x}$ rodzaj ziarna $(\mathrm{P}<0.05)$ u broilerów otrzymujących dawki z jęczmieniem, których wyniki produkcyjne były lepsze w okresic „grower”. U brojlerów otrzymujących dodatek enzymów wystąpiła istotna interakcja enzym x okres dla wykorzystania paszy przez ptaki przyrastające iepicj w okresie "starter" niż "grower" w porównaniu z ptakami żywionymi dawkami nie uzupełnionymi enzymami. Lepkość treści broilerów otrzymujących dawkę MDB była większa niż ptaków otrzymujących zwykły jęczmień, kukurydzę lub pszenicę ( $\mathrm{P}<0,01)$. Dodatek enzymów do dawki MDB wpłynął na zmniejszenic $(\mathrm{P}<0,01)$ lepkości treści o $49 \%$ i poprawę wykorzystania paszy $(\mathrm{P}<0,05)$ w obydwóch okresach warostu. 